\title{
Pursuing Change or Pursuing Credit? Litigation and Credit Claiming on Social Media*
}

\author{
Anna Gunderson $^{\dagger} \quad$ Kirsten Widner ${ }^{\ddagger} \quad$ Maggie Macdonald ${ }^{\S}$
}

September 28, 2021

\begin{abstract}
Social media has become an important tool in interest groups' advocacy toolboxes because it provides an inexpensive and powerful way to communicate with large and diverse audiences. It is a puzzle as to why organizations would spend time posting about tactics that do not typically depend on public opinion or mass mobilization, such as litigation. This paper explores the nature and extent of these posts and we argue there are two primary reasons interest groups post about judicial advocacy on social media. First, organizations may provide information about the courts on social media to build credibility and recognition as a trusted source of information. We hypothesize that membership groups will be less likely to use social media in this way than non-membership public interest organizations. Second, organizations may use social media to claim credit for policy decisions made by the courts in order to increase their public and financial support. We expect that this strategy will be used most frequently by legal organizations. Using an original dataset of millions of tweets and Facebook posts by interest groups involved in litigation, we find support for these expectations and evidence of unique credit claiming activity on Facebook and Twitter. This research provides insight into how, when, and why interest groups share information about the courts, litigation and their involvement therein.
\end{abstract}

* Many thanks to participants at the 2021 Southern Political Science Association (SPSA) and Midwest Political Science Association (MPSA) conferences and the Law and Courts Writing Group for feedback. Many thanks to Kevin Brown for technical assistance and Charlie Cacciatore for excellent research assistance.

${ }^{\dagger}$ Department of Political Science, Louisiana State University, Baton Rouge, LA, USA

† Department of Political Science, University of Tennessee, Knoxville, TN, USA

${ }^{\S}$ Center for Social Media and Politics, New York University, New York, NY, USA 
Today's interest groups represent a dizzying array of interests in the public policymaking process. Everyone from mosquito control professionals to bicycle enthusiasts to seekers of racial justice can find an advocacy organization - often several! - working to advance their interests. These organizations use a wide range of different advocacy tactics in their work, including public education and events, grassroots mobilization, voter registration, direct lobbying, administrative lobbying, media advocacy, and judicial advocacy (Baumgartner and Leech|1998, Grossmann|2012, Guo and Musso 2007). Increasingly, social media has become a part of interest groups' advocacy toolboxes (Chalmers and Shotton 2016). Organizations can use social media to share information, build community, and mobilize action (Guo and Saxton 2014). Put more simply, they may use social media to attract attention to the group and their cause (Guo and Saxton 2020).

Posting on social media about support or opposition for legislation or other policies is often part of a group's mobilization strategy. It provides a low cost way to put out information that can shape public opinion, as well as calls to action for grassroots activity such as protests, demonstrations, or contacting lawmakers (Figenschou and Fredheim 2020). It is less clear why organizations would spend time posting about tactics that do not typically depend on public opinion or mass mobilization, such as litigation. While there is some evidence that courts often act in line with public opinion (see, e.g., Graber 2006, Pope 1990), the courts are generally thought to be insulated from direct pressure from interest groups. While interest groups are active in trying to persuade the courts to adopt their preferred policies, this activity takes different forms than those used to advocate to the legislative and executive branches. Courts are not "lobbied" in the traditional sense. Individuals and interests groups cannot call or visit Supreme Court justices to influence important decisions. Instead, most court advocacy is more formal. It involves representing clients with a legal interest at stake or filing amicus briefs to provide additional information to the court. These formal activities do not leave much room for general public involvement: ${ }^{1}$

This presents a puzzle: why do interest groups spend precious time and resources gathering

\footnotetext{
${ }^{1}$ While protests and demonstrations at the Court have increased, justices find this distressing and contrary to the proper understanding of their role. See, for example, Planned Parenthood of Southeastern Pennsylvania v. Casey, 505 U.S. 833, 999-1000 (1992) (Scalia J. concurring in the judgment in part and dissenting in part).
} 
and sharing information about court cases or court activity with the public through social media, and what do they expect their followers (whether they be members of the group or not) to do with that information? This paper suggests two answers. First, organizations may provide information about the courts on social media to build credibility and recognition as a trusted source of policy information. However, this goal is in tension with the ability to offer information as a selective benefit to gain and retain members. Therefore, we hypothesize that membership groups will be less likely to use social media in this way than non-membership public interest organizations. Second, organizations may use social media to claim credit for policy decisions made by the courts in order to increase their public and financial support. We expect that this strategy will be used consistently by interest groups involved in judicial advocacy, but will be used most frequently by legal organizations seeking to demonstrate their legal acumen and expertise. Notably, neither strategy expects readers of court-related posts to take political action. Rather, both aim to strengthen readers' support of the organization itself.

The paper proceeds as follows. It begins by providing an overview of judicial advocacy by interest groups and exploring the reasons interest groups might post about that activity on social media. It then tests hypotheses about information sharing and credit claiming on two original datasets of Facebook and Twitter posts from over 3,000 advocacy organizations active in federal public policymaking and supreme court advocacy. The results provide support for our hypotheses. The paper concludes by discussing the implications of the findings so far and outlining the next steps for our analysis.

\section{Interest Group Advocacy and the Courts}

Interest groups play a central role in American politics and provide essential representation to their members in the public policymaking process (Baumgartner and Leech|1998). These groups work to influence public policy in a variety of ways (Browne 1998). While legislative advocacy is by far the most common (Nownes and Freeman 1998, Schlozman and Tierney 1986), interest groups also typically pursue a multi-venue strategy that often includes litigating to change policy 
through the courts (Holyoke 2003). In the latter half of the twentieth century, marginalized groups used the court system to obtain recognition of rights previously denied to them (the "underdogs" as one scholar calls them; Epp 1998, Scheingold 1974). However, disadvantaged groups are not alone in turning to the courts (Olson 1990). Interest groups of all kinds have pursued litigation as a means of securing additional rights for their constituencies, when the traditional policymaking process in the electoral branches was less friendly to policy change, and to supplement or enforce existing legislative, executive, or judicial policies (Giles and Walker 1975, Olson 1990).

There are a variety of methods by which interest groups can engage in judicial advocacy. First, they can file lawsuits directly. This is an expensive and time-consuming process with no guarantee of success or substantive policy change (McCann 2006). Even if interest groups win

in the lower courts, their cases may have limited policy effects; only Supreme Court cases have national impact. Lawsuits rarely reach the Supreme Court; the Court only takes about $1 \%$ of the cases they are asked to review each year (and a minuscule $0.02 \%$ of the cases that are filed in the district courts each year).

Second, interest groups can file amicus curiae ("friend of the court") briefs in cases brought forward by other litigants. This option is less resource-intensive than bringing cases directly, but still gives groups the opportunity to shape the content of court opinions, particularly at the Supreme Court level (Hazelton, Hinkle and Spriggs 2019). We will provide a fuller discussion of amicus participation below. As a third alternative, interest groups can seek to influence policy indirectly by shaping the makeup of the courts. They can do this through lobbying efforts directed toward the federal judicial nomination process (Caldeira and Wright 1998, Caldeira, Hojnacki and Wright 2000).

\subsection{Providing Information About the Courts}

A fourth option for interest groups is to keep the group's members or other interested parties apprised of relevant cases decided in the courts. This can be seen as a form of membership main- 
tenance, a goal separate from and in addition to policy aims (Solberg and Waltenburg 2006). Information can be offered as a "selective benefit" of group membership that entices individuals to give time or money to collective action (Olson 1965). When used in this way, receipt of the information is limited to members or supporters of the group. Membership organizations surveyed by Walker (1991) reported that information shared in publications like newsletters and updates is one of the most important benefits for attracting and retaining members. Providing updates also gives organizations an excuse for regular contact with members and supporters. Regular contact serves several goals for an organization: it prompts donations, provides education, and mobilizes members for actions such as voter registration, coalition building, and direct lobbying (Guo and Saxton 2014). Although some scholars have examined how these kinds of informational strategies are used in the modern context through avenues like emails (see, e.g., Vining 2011), newer research extends these insights to the social media context (Brown 2015, Van der Graaf, Otjes and Rasmussen 2016).

Social media complicates the use of information as a selective benefit. Platforms like Twitter and Facebook are generally used to make information available to the widest possible audience, not just to those who are members of a particular group. Information can be obtained by anyone who cares to read what an organization shares..$^{2}$ By not requiring membership to obtain the information, organizations that share updates in this way run the risk that interested parties will free ride, taking the information without offering the organization financial or other support (O1son 1965). Given this risk, what motivates advocacy groups to post on social media? Research suggests that nonprofits, like interest groups, use social media for three primary purposes: to provide information to stakeholders, build community, and mobilize or call people to action (Guo and Saxton 2014). We argue that that there are three possible motivations for posting about the courts on social media, with three different audiences.

First, organizations may believe that it is part of their mission to educate the public or their

\footnotetext{
${ }^{2}$ In theory, organizations could use private social media accounts to share information only with members, but our research shows that this is uncommon. Of the thousands of interest groups for which social media information was collected for this project, only a handful had private accounts.
} 
constituents about important policy issues. Many interest groups, particularly nonprofit advocacy organizations, exist to advance a cause and are highly mission driven (Berry 1977, 2003). Making the information as broadly available as possible helps them to fulfill that mission. Guo and Saxton (2014) found that public education was the most common advocacy tactic on Twitter. Second, organizations may seek to increase their visibility with the news media. Organizations seek media attention to help them spread their message and build name recognition and public support (Schlozman and Tierney 1986). Members of the news media are active on social media, particularly Twitter, and can use social media to diversify their sources (McGregor and Molyneux 2020). A reporter who may not have otherwise thought to reach out to an organization for comment on a court case may be inspired to do so by an insightful post or tweet. Third, organizations may seek to establish or reinforce their credibility with policymakers. Social media audiences include policymakers themselves; most members of Congress, for example, are active on both Facebook and Twitter ${ }^{3}$ Interest groups engage extensively with congressional candidates and members of Congress on Twitter where they follow and mention each other (Macdonald 2020). A reputation as a timely and reliable source for quality information can be a valuable tool for gaining access to and building trust with policymakers. Indirect methods of delivering information, like social media, can be just as valuable, if not more so, in obtaining access to policymakers (Chalmers 2013).

For all of these reasons, interest group organizations may be motivated to share policyrelated information about the courts on social media. However, this approach will be more beneficial for some types of groups than others. Organizations that view public education as part of their mission should be most likely to prioritize sharing this type of information. In contrast, membership groups should be more likely to use information as a selective incentive for membership; thus, they should be less likely to share such information on a public social media account. In the interest group universe, professional associations, business and industry trade associations, and unions all tend to be membership organizations (Walker 1991). Citizens' groups are least likely to

\footnotetext{
${ }^{3}$ Patrick Van Kessel, Regina Widjaya, Sono Shah, Aaron Smith and Adam Hughes, "Congress Soars to New Heights on Social Media, "Pew Research Center, https://www.pewresearch.org/internet/2020/07/16/ congress-soars-to-new-heights-on-social-media/
} 
be membership organizations, and even those that are may have a public interest focus that leads them to value public education over selective benefits (Berry 1977). This leads us to our first two hypotheses:

Hypothesis 1: Interest groups will post about relevant court decisions and activities on Facebook and Twitter.

Hypothesis 2: Citizens' groups will post about relevant court decisions on Facebook and Twitter more often than other types of interest group organizations.

Note that these motivations are not specific to court-related policy information. Thus, we should not expect to see organizations posting updates about the courts exclusively, but instead should expect updates on the courts as part of a more general social media strategy. However, some groups may have additional incentives to post about the courts specifically. Legal organizations like bar associations and public interest law firms may view legal expertise as a key way they can differentiate themselves and provide value in the policymaking process. Therefore, they may use their social media presence to strengthen their reputations as legal experts and effective litigators. This leads to our third hypothesis:

Hypothesis 3: Legal organizations will post about relevant court decisions on Facebook and Twitter more often than other types of interest group organizations.

\subsection{Amicus Briefs and Credit Claiming}

The most common litigation-related strategy for interest groups is writing or signing onto amicus briefs. Amicus briefs allow interest organizations to indicate their preferences to the courts and pool resources with other groups $\left(\right.$ Collins 2004). ${ }^{4}$ These briefs are submitted by groups or individuals who are not parties to the case under consideration but who can add context and information helpful to the court. Supreme Court Rule 37 encourages those filing amicus briefs to supply new information and avoid repeating the arguments of the party they support (Collins 2018), though

\footnotetext{
${ }^{4}$ We examine the Supreme Court context in the review of the literature here, though amicus briefs can be and are filed in the lower federal courts and state courts as well.
} 
the briefs often provide no novel legal arguments not offered by the litigants themselves (Wofford 2015). Organizations can file these briefs alone, or together with other organizations, individuals, or states. Amicus briefs can be filed at either the petition for certiorari stage, to urge the Supreme Court to grant or deny review, or after the justices grant certiorari, at the merits stage. We consider both of these below.

Interest groups file amicus briefs to persuade the justices to decide cases in a manner consistent with their policy preferences (Solberg and Waltenburg 2006, Wofford 2020), though their efforts may not be successful. $5^{5}$ There is some evidence that more amicus brief support is associated with higher litigant success at the merits stage (Kearney and Merrill2000) and the party supported by the largest number of these briefs (and the most experienced lawyers) generally enjoys an advantage in the ultimate adjudication of the case (Collins 2004, Kearney and Merrill 2000, Mak, Sidman and Sommer 2013, McGuire 1995, O'Connor and Epstein 1982, Songer and Kuersten 1995). ${ }^{6}$ This advantage is compounded further by the involvement of high-profile interest groups, like the Chamber of Commerce or the American Civil Liberties Union (Buckler 2015, Epstein 1992, Ivers and O'Connor 1987, Lynch 2004). Briefs can act as a useful signal for justices on the importance or relevance of a particular case, encouraging them to grant review initially or decide a particular way in the merits stage (Caldeira and Wright 1988). Amicus participation is most frequent in salient cases that have the most potential for wide-ranging policy effects (Martinek 2006. Salzman, Williams and Calvin 2011, Zuber, Sommer and Parent 2015). However, increasingly, amicus briefs are filed in nearly all Supreme Court cases (Larsen and Devins 2016).

Empirical evidence suggests that judges use amicus briefs in their work. Supreme Court justices are increasingly likely to cite amicus briefs and sometime even lift language directly from the briefs into their opinions (Collins, Corley and Hamner 2015, Owens and Epstein 2005, Spriggs and Wahlbeck 1997). However, groups' influence depends on a variety of factors, including ideology, case context, policy consensus, and the relative power and connectedness of the group in

\footnotetext{
${ }^{5}$ Organizations and individuals can also file amicus briefs that do not support either party (i.e. the respondent or the petitioner), though these are much less common.

${ }^{6}$ Though, see Songer and Sheehan (1993) for counterevidence of this phenomenon.
} 
broader interest group networks (Bils, Rothenberg and Smith 2020, Box-Steffensmeier, Christenson and Hitt 2013, Christenson and Box-Steffensmeier 2017, Hazelton, Hinkle and Spriggs 2019).

In addition to their practical value, amicus briefs may be normatively important as well. They provide entry into the judicial arena without the expense of directly bringing a lawsuit, potentially increasing the democratic responsiveness of the court and leveling the playing field for groups with varying resources (Chang and Wang 2008, Edwards 2017, Garcia 2007, Simmons 2009). There is no evidence that any one organizational type - whether it be trade groups, citizens' or public advocacy groups, unions, or other types of interest groups (see below for explanations of these types) - dominates the amicus process (Collins 2008, Collins and Solowiej 2007). However, although amicus briefs are cheaper than engaging directly in litigation, they are not costless; interest groups need to commit time and legal resources to write a brief themselves or partner with other groups (Caldeira and Wright 1988) or attorneys. Some research suggests that the most well-established and best resourced interest groups are the most likely to use all litigation strategies, including amicus participation (Walker 1991).

Regardless of precisely how and whether these briefs actually influence judicial behavior, it is common for organizations to credit claim for this activity, to draw attention to the group's participation and interest in a particular policy area. Specifically, if the brief plays a role in getting the Court to grant certiorari or in the eventual outcome of the case, organizations can claim (at least partial) credit for this decision (Collins 2018). Indeed, there is evidence that organized interests seek out the cases in which justices are information-poor and those cases that allow for participation that is highly visible to the group's members, through the media or other avenues (Hansford $2004 a b) .7$ Like sharing information about the courts, credit claiming is more about organizational maintenance and generating support than it is about advocacy. In other words, sharing the fact that a brief was filed with members or the public is not intended to seek additional advocacy action but

\footnotetext{
${ }^{7}$ Interest groups can also claim credit for influencing appointment of Supreme Court justices, though that influence is likely small (Segal, Cameron and Cover 1992, Shapiro 1989).
} 
rather to demonstrate the value of the interest group organization.

\subsection{Social Media as an Avenue for Credit Claiming}

In the past, organizations were fairly limited in the methods they could use to educate their members about their amicus activity (like email; Vining 2011). Now, however, social media provides a cheap and easy means of reaching out to members, supporters, and potential supporters. These individuals and groups may see an organization's social media posts as they occur, by following the organization or seeking out information on topics that they care about through the use of relevant hashtags (for a discussion of this strategic behavior by Congress, see Hemphill, Culotta and Heston 2013). Interested parties can also go back to an organization's Twitter or Facebook page and see all of its previous posts. In this way tweets and Facebook posts offer something different from similar communication tools like email — a way for anyone to learn about an organization's priorities, statements, and activities over time. We theorize that social media is an essential new avenue for interest groups to credit claim for their litigation activity, specifically in reference to amicus briefs.

Interest groups consider media attention given to similar cases when deciding whether to file amicus briefs (Hansford 2004b). Cases that receive more attention are more likely to bring the type of positive credit an organization seeks. However, with the use of social media, interest groups, as well as other actors such as members of Congress Ansley and Sellers 2010, Johnson 2011), are no longer exclusively reliant on those in the news media to publicize their litigation activities. Social media provides a low cost method of publicizing a group's own efforts, bypassing the media altogether and allowing these groups to engage policymakers, the public, and other audiences directly (Figenschou and Fredheim 2020, Gainous and Wagner 2014, Golbeck, Grimes and Rogers 2010, Johnson 2011). While such an inexpensive tool may be useful for all organizations, it is likely to be particularly important for those with fewer resources because social media increases the frequency and ease with which they can communicate to a wide range of audiences while incurring no expense other than the cost of their time. 
Although there is a burgeoning literature on how interest groups use social media to engage in lobbying (e.g., Bortree and Seltzer 2009, Chalmers and Shotton 2016, Lovejoy, Waters and Saxton 2012, Obar, Zube and Lampe 2012, Widner, Macdonald and Gunderson 2020), so far it offers little insight into how interest groups use social media to credit claim for their amicus activity in the courts. We extend theories of credit claiming to this essential, low-cost context and hypothesize that interest groups will use social media to publicize their amicus activity to their members.

Hypothesis 4: Interest groups that draft or participate in amicus briefs will credit claim by posting about their amicus activity on Twitter and Facebook.

As with information sharing about the courts generally, legal organizations may be particularly likely to credit claim for amicus activity. Supporters of legal organizations are more likely to expect them to participate in relevant cases. This leads to an additional hypothesis:

Hypothesis 5: Legal organizations will credit claim by posting about their amicus activity on Twitter and Facebook more frequently than other types of organizations.

\section{Data and Methodology}

We collected data on two sets of interest groups for this project. First, to examine the general behavior of interest groups, we used a list of over 1,700 advocacy organizations compiled by Grossmann (2012). We verified that the organizations were still active by checking their websites. For organizations that no longer had active websites, we did further web searches that sometimes identified other organizations that had absorbed the original organization or stepped into the space left by an organization that had become defunct. We also consulted lists of leading trade associations, professional associations, and citizens' groups to identify organizations not included in the Grossmann (2012) data ${ }^{8}$ This process resulted in a list of 1,684 organizations currently active in

\footnotetext{
${ }^{8}$ Sources for these lists included: a Wikipedia list of trade associations: https://en.wikipedia. org/wiki/List_of_industry_trade_groups_in_the_United_States, The Reference for Business list of the largest professional associations: https://www.referenceforbusiness.com/encyclopedia/Per-Pro/ Professional-and-Trade-Organizations.html; and UCLA'S Civil Rights Project's list of leading civil rights groups: https://www.civilrightsproject.ucla.edu/resources/civil-rights-organizations.
} 
lobbying the U.S. federal government. These organizations form the basis for what we will refer to as our "federally-focused dataset."

Second, to examine the particular behavior of organizations that file amicus briefs, we created a list of every interest group that wrote or signed onto an amicus brief before the U.S. Supreme Court over the four most recent terms (2016-2020). This list forms the basis for what we will refer to as our "amicus dataset" and includes over 2,500 state and national organizations, less than $20 \%$ of which were on our original list of federally-focused organizations. Both lists were then hand-coded into four discrete categories:

Business and Industry Groups are trade associations and other organizations that aggregate the interests of businesses or industrial sectors. Examples of organizations in this category include the Aluminum Association and the National Women's Business Council.

Professional Organizations are organizations that are centered around a particular profession or occupation. Examples of organizations in this category include the American Political Science Association and the American Medical Association.

Unions are labor unions that advocte and bargain collectively on behalf of workers. Examples of organizations in this category include the National Writers Union and the American Postal Workers Union.

Citizens' Groups are organizations that centered around identities or issues that are not primarily economic or professional in nature.Examples of organizations in this category include the NAACP, AARP, and the World Wildlife Fund.

Additionally, to test Hypotheses 3 and 5, we also handcoded whether each interest group was a legal organization. Most legal organizations in the data are either bar associations (which are professional organizations) or public interest law firms (which are citizens' groups), though a handful were legal defense funds set up for litigation affecting particular professions or types of businesses. 


\subsection{Data Collection: Facebook and Twitter}

Using the federally-focused and amicus lists of organizations, we collected all posts they made on both Facebook and Twitter. We used CrowdTangle to collect all Facebook posts from organizations' public pages from January 1, 2016 to December 31, 2020. This results in two datasets, based on our two lists of organizations, totaling over 6 million Facebook posts.

We collected the Twitter handle of each organization (their unique Twitter username) using links from the organization's website and Google. We collected Twitter data using its Academic Research API (application programming interface). We gathered all tweets from our groups from January 1, 2016 to December 31, 2020 (the same time period as the CrowdTangle data). For each organization, we collected several pieces of information about each account and its posts. This includes, but is not limited to, the organization's number of followers and total number of tweets, as well as the text of each tweet, the number of likes and retweets it has, and its date of creation. Each list of organizations generated about 10 million unique tweets, for a total of almost 20 million between Facebook and Twitter.

\section{Court and Amicus Posts on Social Media}

Recall that Hypotheses 1, 2, and 3 propose that interest groups will post about relevant court decisions and court activities on Facebook and Twitter, and that citizens' groups and legal organizations will be most likely to do so. These hypotheses were tested on our federally-focused dataset, which is a more representative of the range of different organizations involved in policymaking, not just those that have been active in the Supreme Court. For a preliminary analysis of this phenomenon, we coded posts and tweets using a dictionary method. We labeled a post or tweet as about the courts generally if it contains at least one of the keywords "SCOTUS", "Supreme Court", "District Court", "Circuit Court", “court ruling", "court decision”, "lawsuit fil”, "filing a lawsuit", "filed a lawsuit", "court filing", "friend of the court," “amici", or "amicus.' 9

\footnotetext{
${ }^{9}$ The text matching method that we use labels a post if the keyword or phrase is contained in its entirety - for example "lawsuit fil" would label posts containing both "lawsuit filed" and "lawsuit filing" as related to the courts.
} 
Since January 1, 2016, there were 25,541 Facebook posts made by 854 unique groups in our federally-focused data that included at least one of these keywords or phrases. During the same period 189 groups tweeted about the courts 16,644 times. Across the two platforms, though some of the groups mention the courts and their decision-making only once, many post about these issues more frequently. The summary statistics for the organization's Facebook and Twitter posting behavior are shown in Table 1. More than half of the 1,500 federally-focused groups that have social media accounts posted about the courts at least once on at least one platform between January 2016 and December 2020 10

While we do a more specific test below of Hypotheses 4 and 5 regarding posts about amicus activity using the amicus dataset, we also examine posting about amicus briefs within the federallyfocused dataset. If a Facebook post or tweet included either "friend of the court," "amici," or "amicus" it was labeled as an amicus post. This is a conservative method of capturing these posts. 1,329 Facebook posts, made by 329 unique groups, and 571 tweets, made by 70 unique groups, included one of these three words, as shown in Table $1^{11}$ Approximately one-fifth of the organizations in our federally-focused sample posted on Twitter or Facebook about amicus briefs at least once.

Table 1: Organization Posts Summary Statistics, January 1, 2016 to December 31, 2020 of the number of Facebook posts or tweets made by federally-focused groups about courts, amicus briefs in particular, or specific Supreme Court case names, for those who posted about each topic at least once.

\begin{tabular}{llccccccc}
\hline \hline Platform & Topic & N Groups & Mean & St. Dev. & Min & Pctl(25) & Pctl(75) & Max \\
\hline Facebook & Courts & 854 & 29 & 72 & 1 & 2 & 22 & 718 \\
Facebook & Amicus & 329 & 4 & 7 & 1 & 1 & 3 & 51 \\
Facebook & Case Names & 218 & 7 & 21 & 1 & 1 & 6 & 288 \\
Twitter & Courts & 189 & 88 & 320 & 1 & 1 & 34 & 2,515 \\
Twitter & Amicus & 70 & 8 & 23 & 1 & 1 & 6 & 186 \\
Twitter & Case Names & 49 & 9 & 28 & 1 & 1 & 5 & 153 \\
\hline
\end{tabular}

\footnotetext{
${ }^{10}$ See the appendix for the top filers by group type and group name on both Facebook and Twitter.

${ }^{11}$ There are a couple of false positives which we exclude from the data presented here - mainly references to Representative Suzanne Bonamici (@RepBonamici), who represents Oregon's 1st district in the U.S. House, but also Twitter user @ amicusrx1 and mentions of the "Amicus Podcast" from Slate.
} 
Additionally, we created a dictionary of case names of the 278 cases brought before the Supreme Court from 2016 to 2020 in our data to label the tweets and Facebook posts which mentioned cases by name. We took every case name and include different variations of the name in the dictionary. For example, to label tweets about Little Sisters of the Poor Saints Peter and Paul Home v. Pennsylvania (2020) the dictionary includes variations such as Little Sisters of the Poor v. Pennsylvania and Little Sisters of the Poor v. PA. Accounting for these alternative case names, this dictionary contains 981 unique terms (that correspond to the 278 unique cases). Note that this includes any mention of a case name by an interest group on these platforms- whether or not they filed an amicus brief on the case.

Table 1 includes summary statistics of the case names dictionary as well, and we see greater variation between the two platforms that we do with the courts and amicus dictionaries. Over four times as many groups on Facebook mentioned at least one Supreme Court case by name (218) than on Twitter (49), though the average group who tweeted at least once about a specific case did so more frequently than on Facebook. In the following sections we dive deeper into interest group behavior on Twitter and Facebook.

\subsection{Content Analysis of Court-Related Posts}

To get a better sense of what interest group organizations are actually posting about the courts, we took a closer look at a random sample of 200 Facebook posts and 200 Twitter posts that our dictionary approach identified as court-related posts and conducted a content analysis of that random sample. Figure 1 provides some examples of posts and tweets that were coded as court-related posts on Twitter (Figure 1a and 1b) and Facebook (Figure 1c and 1d).

Many posts and tweets give updates on cases. For example, 3\% of Facebook posts and $1.5 \%$ of tweets in the content analysis announced that a lawsuit had been filed. About $8 \%$ of Facebook posts and 5\% of tweets announced that cases have been appealed to a higher court or have oral argument presented. About $14 \%$ of the Facebook posts and $16 \%$ of the tweets informed 


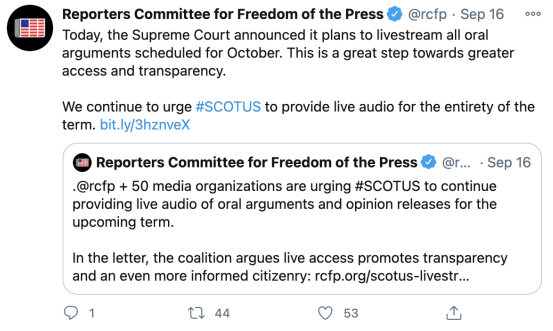

(a) Twitter Example 1

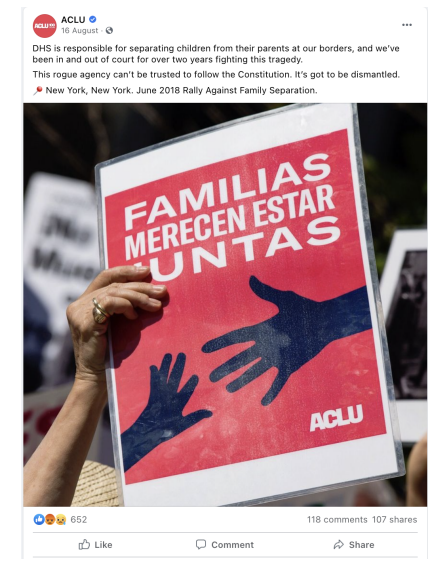

(c) Facebook Example 1

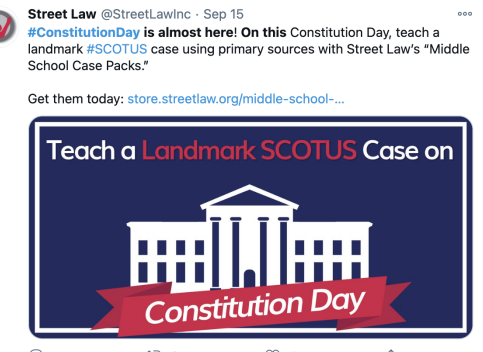

(b) Twitter Example 2

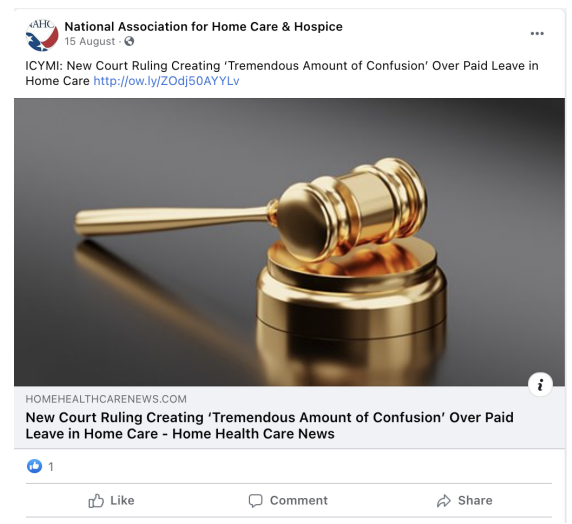

(d) Facebook Example 2

Figure 1: Examples of court-related posts on Facebook and Twitter.

readers that the Court had reached a decision in a particular case. Only 5\% of the Facebook posts and $2.5 \%$ of the tweets informed readers about the possible effects of the decisions. With regards to decisions and their impact, most posts did one or the other - very few Facebook posts and no tweets talked about about the effect of a decision in the same post in which they announced that the decision had been reached. This suggests that organizations are using social media to share general updates on the progress of litigation more than they are using it to educate their audiences about the outcomes of cases. The vast majority of court-related posts we examined (81.5\% of Facebook posts and 78\% of tweets) discussed the US Supreme Court, though discussion of state court and lower federal court decisions do come up in the sample.

Within the content analysis sample, posts related to judicial nominations were among the most frequent types of content. Given that three Supreme Court justices were nominated during the date range of our data (Neil Gorsuch in 2017, Brett Kavanaugh in 2018, and Amy Coney Barrett in 
2020), it is perhaps unsurprising that about $20 \%$ of the court-related Facebook posts and $27.5 \%$ of the court-related tweets were about the judicial nominees. There are some interesting differences between Facebook and Twitter with regard to the topic of the posts. The Facebook posts were more likely be educational in focus; they provide readers with information about the nominee and the organization's position on whether the person should be confirmed. In contrast, the tweets were more likely to involve a call to action, encouraging readers to sign petitions or call their Senators to support or oppose the nominees.

Consistent with our credit claiming hypotheses, $18.5 \%$ of the court-related Facebook posts and $15 \%$ of the tweets analyzed highlighted the organizations' own involvement in judicial nominations or cases. Organizations promoted their own rallies and amicus briefs, and also touted instances when the court or the media in covering the court cited their briefs, research, or other advocacy.

\subsection{Variation by Group Type}

To test our expectation that there will be variation in court posts between different types of interest groups, we consider the four types introduced above: business, professional, citizens', and union groups. We expect that citizens' groups will post the most about court activity. A plot of the weekly average court posts by each type of group is shown in Figure 2. Averages by group type are used for comparability, because we have different numbers of groups of each types. The plots

provide evidence in support of Hypothesis 2; citizens' groups consistently post the most frequently about courts. Over time, the average weekly number of courts posts for most groups hovers near 10. However, there is evidence of some seasonality where the frequency of posts increases in the summers - particularly during the summers of 2018, 2019, and 2020. This is interesting, given that the Supreme Court typically goes into recess at the beginning of the summer. However, this activity could be driven by opinion announcements at the end of the term.

Because they use weekly averages, these plots cannot tell us whether these trends are driven 


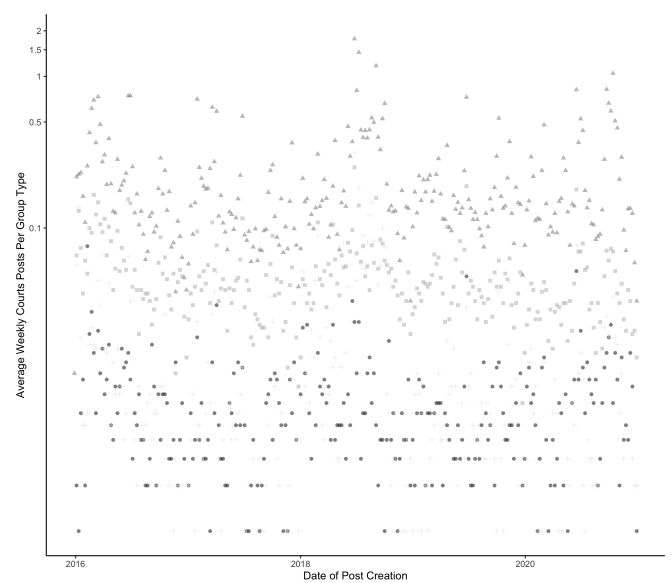

(a) Twitter

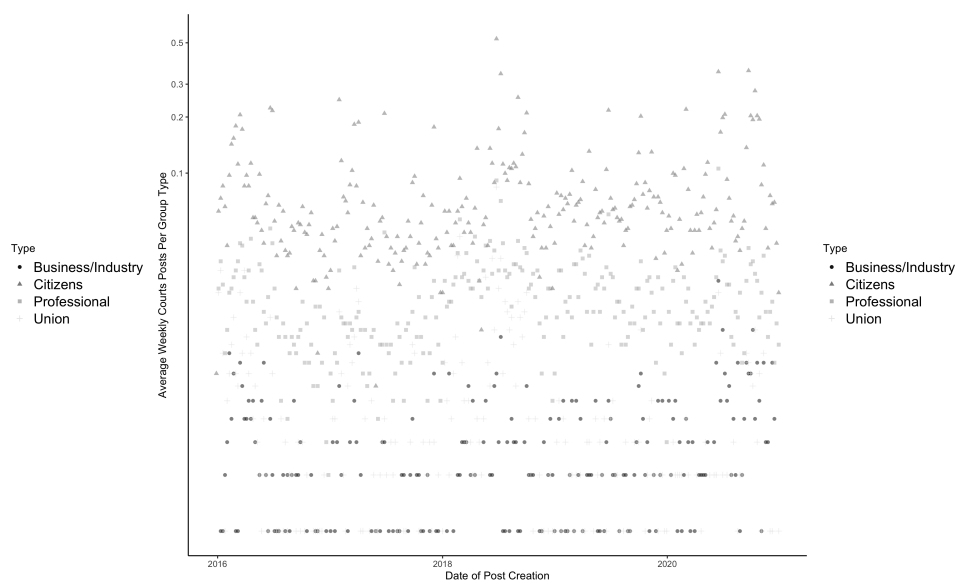

(b) Facebook

Figure 2: Weekly average court posts by group type, January 1, 2016 to December 31, 2020. Tweets are shown on the left (2a) and Facebook posts are shown on the right (2b).

by a small number of organizations within a given type or are instead more widespread. Which organizations are the most frequent posters on Twitter and Facebook about the courts? We will consider each in turn, starting with Twitter. The top 20 organizations on both platforms are shown in the Appendix. Of the top 10 most frequent tweeters about courts, all but two were citizens' groups. They were: the People for the American Way (2,519 posts), NAACP Legal Defense and Educational Fund (2,506 posts), the American Constitution Society (the only professional group in the top 10, 2,459 posts), Alliance for Justice (2,447 posts), and Leadership Council on Civil Rights (2,260 posts). The next five were mostly citizens' groups - NARAL Pro-Choice America, Americans United for Separation of Church and State, Lawyers' Committee for Civil Rights Under Law, and the Family Research Council. One was a union, the Service Employees International Union.

Next, we consider the top 10 groups who posted the most Facebook posts on this topic. As with Twitter, 8 out of the top 10 are citizens' groups. The most prolific group is the professional group the Federalist Society (718 posts), followed by citizens' group CAIR (Council on AmericanIslamic Relations, 679 posts), the ACLU (591 posts), the People for the American Way (citizens, 578 posts), and another professional group, the American Constitutional Society (551 posts). Finishing up the top 10 are all citizens' groups: Lawyers' Committee for Civil Rights Under Law, the 
Death Penalty Information Center, the Center for Reproductive Rights, Americans United for Separation of Church and State, and Alliance for Justice. It is striking that only one union - Service Employees International Union - breaks the top 20 on both Facebook and Twitter, at number 19 and number 8, respectively. Even more striking is the complete lack of business groups in the top 20 most frequent posters on the courts on both Twitter and Facebook.

When considered with the general trends shown in Figure 2, the predominance of citizens' groups among the most frequent posters about the courts generally on Twitter and Facebook provides additional support for Hypothesis 2. Though there is some overlap in which groups are the most prolific posters between platforms, the composition of the top groups are largely different. This is worth further exploration, especially considering the trends in Table 1 - the overall number of groups who posted, and the frequency with which the average group posts, on Twitter and Facebook about courts are relatively similar but these trends are not being driven by the same groups across the two platforms.

\subsection{Legal Organizations}

Notably, all of the professional groups that are among the most frequent posters about courts, and about half of the citizens groups fall within the category of legal organizations, despite that fact that these organizations make up a very small proportion of the organizations in the federally-focused dataset. Of the 1,684 federally-focused organizations in our data, 75 of them (about $4.5 \%$ ) are what we consider legal organizations and the remaining 1,609 are not. We predicted in Hypothesis 3 that these organizations will post more often about the courts and court decisions than non-legal organizations. Figure 3 shows evidence in support of this Hypothesis for these groups on Twitter and Facebook by dictionary. This highlights the percentage of courts, amicus, or case name posts by group type, either legal or non-legal. Though the majority of posts are written by non-legal groups, there are many more groups in this category - 778 compared to 64 . So, while legal groups are posting as a lower percentage than non-legal groups, they are posting much more frequently than their non-legal counterparts. We take this as evidence of our hypotheses. 

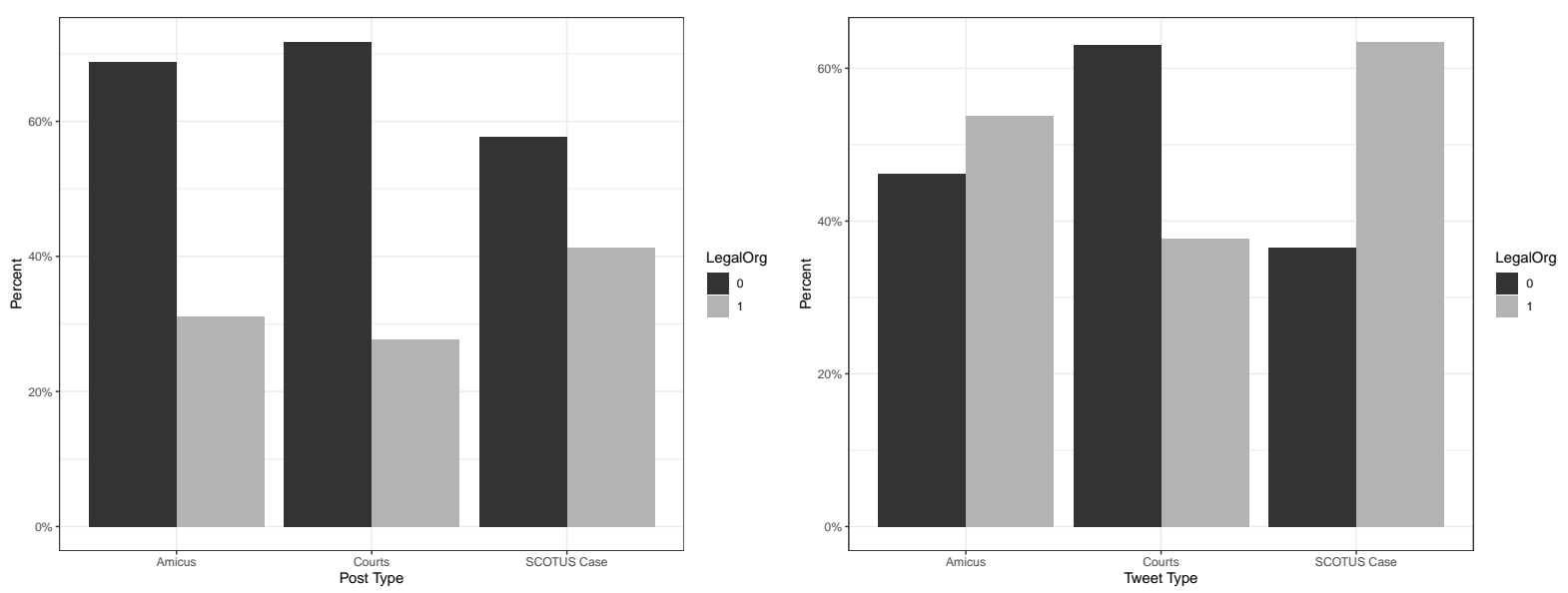

Figure 3: The percent of amicus, court, or case posts by type of organization, legal or not, on Facebook (left) and Twitter (right). In our general courts dataset, there are 778 non-legal groups and 64 legal groups

\section{Credit Claiming for Amicus Briefs}

For our analysis of our credit claiming hypotheses (H4 and H5), we begin by looking at the content of a random sample of 100 Facebook posts and 100 tweets in our federally-focused dataset containing the words "amicus" or "amici." In the majority of these posts (59\% on Facebook and $64 \%$ on Twitter), organizations were explicitly claiming credit for an amicus brief. The vast majority of these posts were credit claiming for filing a brief. Many of these posts acknowledge co-filers highlight the strength of the coalition in support of their position. The tweet from the American Association for the Advancement of Science in Figure 4 is representative. A smaller proportion link the organization's amicus brief to the outcome of the case. Generally, these posts note that their side was victorious, but do not go so far as to say they caused the victory. ${ }^{12}$ The Facebook post from Girls, Inc. in in Figure 4 is representative of this type of post. The remaining posts that mention amicus briefs fall into two general categories. Some thank or acknowledge other organizations for filing amicus briefs. Often these posts also serve to remind readers of the organization's own position on the issue. Others provide general information about who has filed a brief in the case. Most of these seem to provide general education about the case. Occasionally,

\footnotetext{
${ }^{12}$ Interestingly, on both Facebook and Twitter, amicus posts received significantly fewer likes and shares. See the appendix.
} 
however, these posts provide an endorsement of the filer. For example, there are a few instances in the sample where a congressperson or a executive agency nominee had participated as in an amicus brief on the side of a case favored by the organization, and the organization was advocating support of that person because of it. Interestingly, despite the fact that these samples were pulled from our federally-focused dataset, the posts and tweets do not overwhelmingly focus on the US Supreme Court. Approximately $10 \%$ of the posts we examined for the content analysis dealt with amicus activity in state courts, and almost one quarter of them dealt with amicus activity in the lower federal courts. These proportions are notably different from those in our content analysis of more general court-related posts, which were overwhelmingly about the US Supreme Court. This suggests that while federally-focused organizations will primarily provide updates and general information about the Supreme Court, they will credit claim for their amicus activity in any court in which they are active.

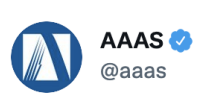

AAAS joins @APSphysics and 15 scientific societies in amicus brief supporting university lawsuit that seeks to prevent @ICEgov from canceling visas of international students \#SciencelsInternational \#StudentBan

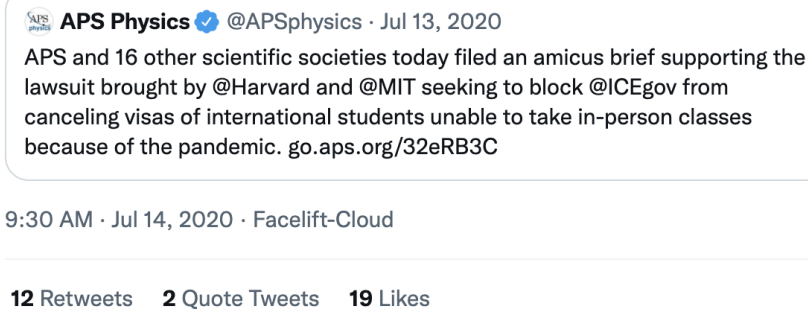

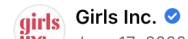

In 2019, Girls Inc was proud to sign on to one of the amicus briefs filed in this Supreme Court case to prohibit discrimination based on gender identity. We are even prouder now to see the rights of our ... LGBTQ community upheld by the Court!

https://www.nytimes.com/.../gay-transgender-workers...

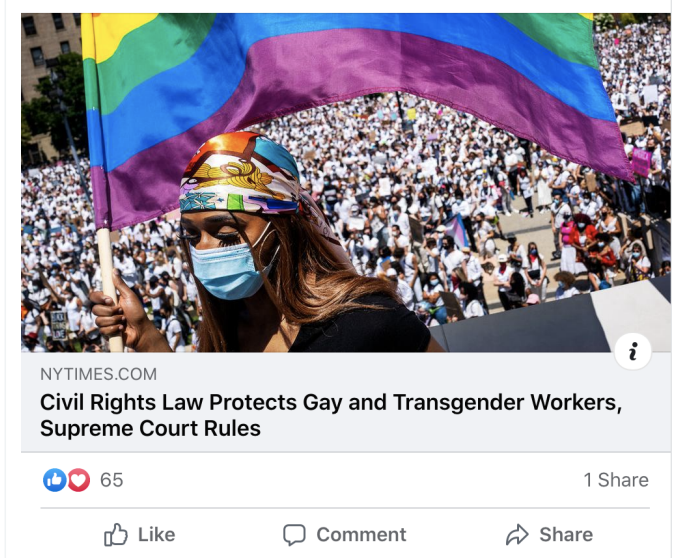

Figure 4: Examples of Credit Claiming Tweets and Posts.

To complement the content analysis, we consider a subset of tweets and Facebook posts those that are about the courts broadly or those that mention either a case name or an amicus term. Here we expand beyond the federally-focused dataset to consider all posts from those groups along with posts from all groups that filed an amicus brief in Supreme Court cases from 2016-2020. We 
consider any posts which included at least one word or phrase from our three dictionaries (courts, amicus, and case names). In total, this subset includes about 98,000 Facebook posts from about 2,000 groups and 156,000 tweets from 1,779 groups. We consider two categories in our data: first, those that filed at least one amicus brief from 2016 to 2020 ('amicus organizations') and second, those federally focused organizations that did not file an amicus brief in the US Supreme Court in that time period ${ }^{13}$ We also consider whether those organizations were legal organizations or not. In total, then, we compare four mutually exclusive groups: legal amicus, legal non-amicus, non-legal amicus, and non-legal non-amicus organizations.

\begin{tabular}{lrr}
\hline & Posts About Amicus Case & Posts Unrelated to Amicus Case \\
\hline Legal Amicus & 859 & 34373 \\
Legal Non-Amicus & 215 & 26 \\
Non-Legal Amicus & 1722 & 57688 \\
Non-Legal Non-Amicus & 131 & 1021 \\
\hline
\end{tabular}

Table 2: Court posts by organizations related to cases they filed amicus briefs in or not, out of a total of 98257 posts about the courts. There are 579 legal amicus groups, 27 legal non-amicus groups, 1964 non-legal amicus groups, and 1024 non-legal non-amicus groups.

Tables 2 and 3 test Hypotheses 4 and 5 for interest groups on Facebook. Table 2 shows the number of posts, out of the approximately 98,000 total, by amicus and legal organization category and whether those groups mentioned specifically a Supreme Court case by name. We consider the approximately 1,500 posts by the amicus filing organizations who posted about their case and actions to be evidence of credit claiming and support for Hypothesis 4 (this sums the posts from legal and non-legal amicus groups). The average legal amicus filer made a Facebook post including a Supreme Court case name over the 4-year period of our data. This is not many but, is substantially more than the average for non-legal amicus filers ( 0.12 posts in 4 years $)$ and non-legal, non-amicus filers ( 0.9 posts in 4 years). The highest average number of posts involving case names actually come from legal organizations that did not file briefs in these cases. We suspect that those are

\footnotetext{
${ }^{13}$ This means that this latter category is comprised of those federally-focused organizations from Section 3 that did not file any amicus briefs in Supreme Court cases. As we noted in the content analysis, organizations do not just post about amicus activity in the US Supreme Court, but rather post about their activity in any court. It is possible that organizations coded as non-amicus for this analysis are amici in other courts. Therefore, credit claiming by amicus organizations may be undercounted in this analysis.
} 
likely posts that aim to inform their members about changes in the law and activities at the court (following our $\mathrm{H} 3$ expectation about legal organizations prioritizing providing information about the courts).

\begin{tabular}{lrr}
\hline & Posts About Amicus Terms & Posts Unrelated to Amicus Terms \\
\hline Legal Amicus & 3493 & 31739 \\
Legal Non-Amicus & 8 & 233 \\
Non-Legal Amicus & 3758 & 55652 \\
Non-Legal Non-Amicus & 22 & 1130 \\
\hline
\end{tabular}

Table 3: Court posts by organizations related to amicus terms, out of a total of 98257 posts about the courts. There are 579 legal amicus groups, 27 legal non-amicus groups, 1964 non-legal amicus groups, and 1024 non-legal non-amicus groups.

Perhaps, however, organizations are mentioning their amicus work and referencing the policy issue rather than the name of the case. To find out, Table 3 shows a similar breakdown of posts except now instead of looking for case names we consider all posts that include terms from our amicus dictionary. This approach identifies many more posts by legal amicus organizations (an average of 6 per organization over the 4 year period). The average number of posts for non-legal amicus organizations, however, drops to 0.3 posts in 4 years, compared with 8 using the case name approach. This suggests that the legal organizations that file amicus briefs may be using more technical legal terms, while the non-legal amicus filers are relying on the case names instead. Most surprising in Table 3 is the relatively high number of posts made by non-legal, non-amicus filing organizations using amicus terms. In future work we intend to take a closer qualitative look at these posts to see if these involve cases filed in other (state or lower federal) courts, as suggested by the content analysis, or whether interest groups are claiming credit for other organizations' work.

Tables 4 and 5 perform the same comparisons as above using the Twitter data. These tables contain all tweets by all organizations who filed at least one amicus brief from 2016-2020, from both the federally-focused and amicus datasets. The trends in number of tweets is similar to the trends in number of Facebook posts- posting behavior about specific cases and amici generally are done primarily by those who filed briefs themselves. This evidence of credit claiming by interest 


\begin{tabular}{lrr}
\hline & Tweets About Amicus Case & Tweets Unrelated to Amicus Case \\
\hline Legal Amicus & 1939 & 56000 \\
Legal Non-Amicus & 133 & 2463 \\
Non-Legal Amicus & 2378 & 89252 \\
Non-Legal Non-Amicus & 71 & 2641 \\
\hline
\end{tabular}

Table 4: Court tweets by organizations related to cases they filed amicus briefs in or not, out of a total of 155990 tweets about the courts. There are 425 legal amicus groups, 3 legal non-amicus groups, 1230 non-legal amicus groups, and 117 non-legal non-amicus groups.

groups on Twitter offers additional support for Hypothesis 4.

\begin{tabular}{lrr}
\hline & Tweets About Amicus Terms & Tweets Unrelated to Amicus Terms \\
\hline Legal Amicus & 4071 & 53868 \\
Legal Non-Amicus & 24 & 2572 \\
Non-Legal Amicus & 3460 & 88170 \\
Non-Legal Non-Amicus & 88 & 2624 \\
\hline
\end{tabular}

Table 5: Court tweets by organizations related to amicus terms, out of a total of 155990 tweets about the courts. There are 425 legal amicus groups, 3 legal non-amicus groups, 1230 non-legal amicus groups, and 117 non-legal non-amicus groups.

In Table 4, we see that the total number of tweets about amicus cases is similar for legal and non-legal amicus organizations, though higher for the former. However, when we consider this in light of the number of groups in each category, we find that legal amicus filers posted with case names an average of 4.6 times during the 4 years of our data, while non-legal amicus organizations posted an average of 2 times. This dynamic is even more pronounced in Table 5. There we see legal amicus-filers posted an average of 9.6 times, while non-legal filers posted 2.8 times. While the total number of tweets by non-legal non-amicus organizations was greater than the number from legal amicus organizations, there are many more non-legal organizations than legal organizations in our data, the average legal group tweeted more (engaged in more credit claiming) than the average non-legal group. This offers further support for Hypothesis 5.

\subsection{Timing of Posts}

In the final piece of analysis, we consider the timing of posts about cases. The analyses above seek to understand whether and to what degree groups are credit claiming for their amicus activity 
on Facebook and Twitter. One outstanding question, though, is how this posting aligns with the timing of Supreme Court decisions. Are groups posting before or after the announcement of the granting of certiorari (when the Supreme Court agrees to hear the case), the oral argument date, or the date the decision is ultimately announced? We next compare the timing of the posts to these important case dates.
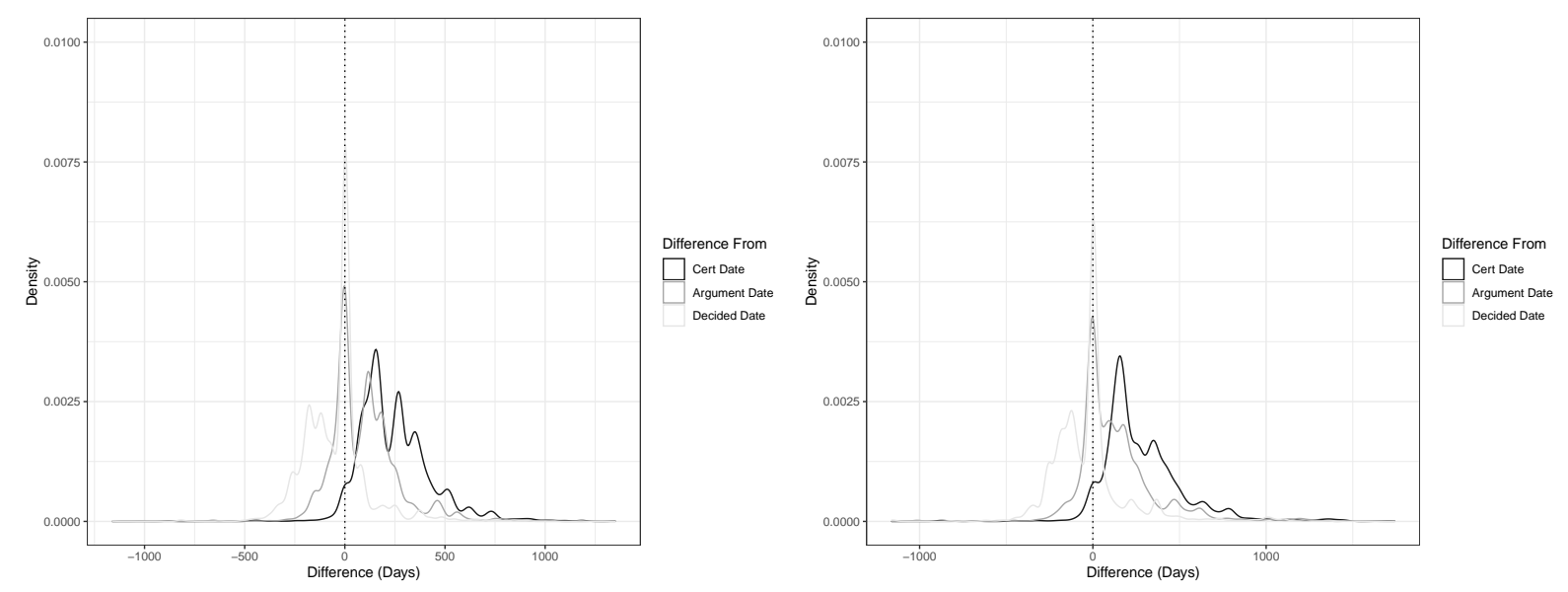

Figure 5: Difference in days from Facebook and Twitter posts about Supreme Court case to the cert, argument, or decision date among groups that filed amicus briefs at the Supreme Court from 2016 to 2020 .

Figure 5 shows the density of posts matched to their Supreme Court case by the distance, in days, from the cert, argument, and decision dates. Remember that interest groups can file amicus briefs at two stages: when the court is considering whether to grant certiorari and when the court is considering the merits of a case in which certiorari has already been granted. If organizations were credit claiming for filing amicus briefs supporting (or opposing) certiorari, we would expect to see a spike of activity before certiorari is granted, but we do not see that. The vast majority of posts come after the Court has chosen to hear the case. Instead posts about a case tend to build slightly before the case is argued, when most amicus briefs are filed, and around the argument date itself, when news coverage of the case may be prominent. We also see that the majority of posts occur before the case is decided rather than after. This comports with our credit claiming hypotheses, as it demonstrates that organizations are posting in the lead-up to a Supreme Court decision, likely to inform readers about the organizations' efforts to sway the courts. It is also consistent with our 
content analysis, which found that organizations posted more frequently about filing amicus briefs than they did about the results of their efforts in those cases. Are these patterns consistent across group types, however? We next consider whether these temporal patterns differ by whether an interest group is a legal organization.
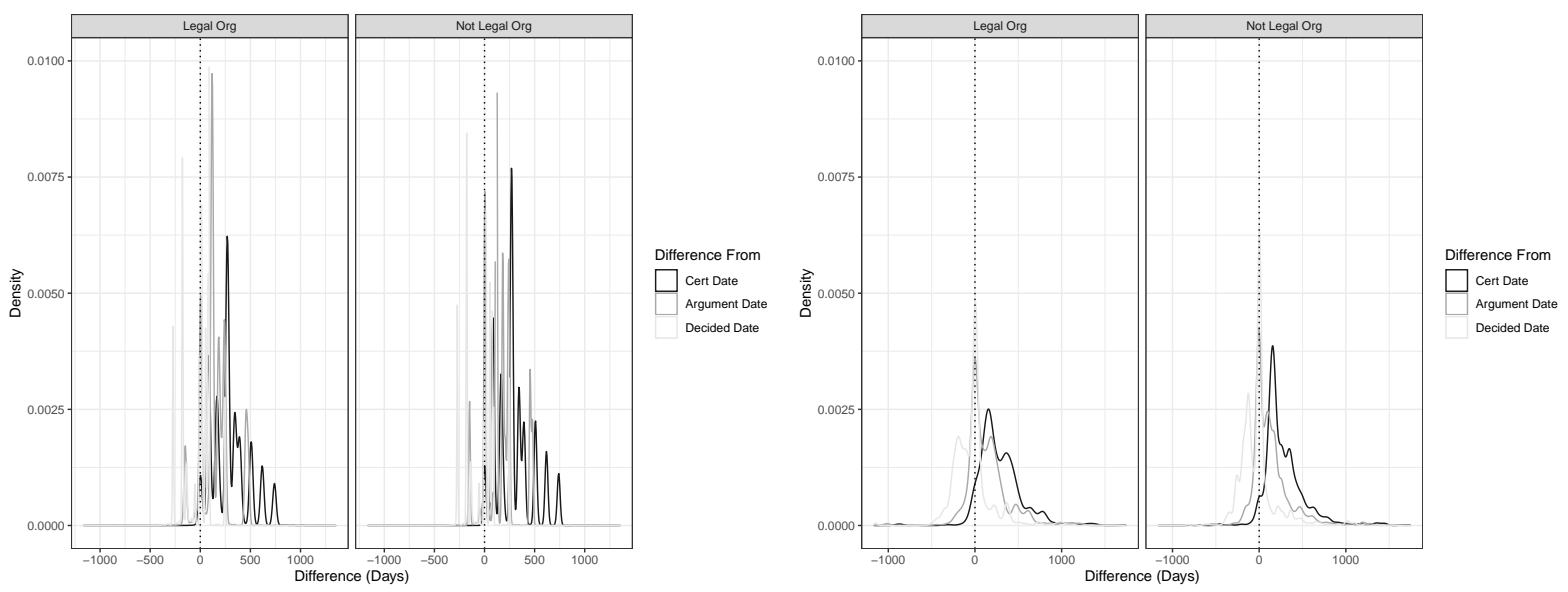

Figure 6: Difference in days from Facebook and Twitter posts about Supreme Court case to the cert, argument, or decision date for legal and non-legal organizations that filed amicus briefs at the Supreme Court from 2016 to 2020.

Figure 6 highlights that these patterns do indeed differ by whether the organization is classified as legal or not. For instance, legal organizations (at least in the Twitter data) appear to post more consistently about their amicus activity throughout the Supreme Court case process, from certiorari to argument and decision dates. The pattern for Facebook is a less clear, with large variability in posting activity for legal and non-legal organizations. Nevertheless, however, the more consistent posting from legal organizations appear to also exist in the Facebook data.

Finally, we consider whether these patterns are different by group type in Figure 7 . We do see qualitative differences in posting behavior between group types: business and industry groups, for example, tend to post before the decision date but after the case is granted cert. Activity of unions, on the other hand, appears to be concentrated after each milestone date. This analysis suggests that there may be important differences by group type in credit claiming behavior. 

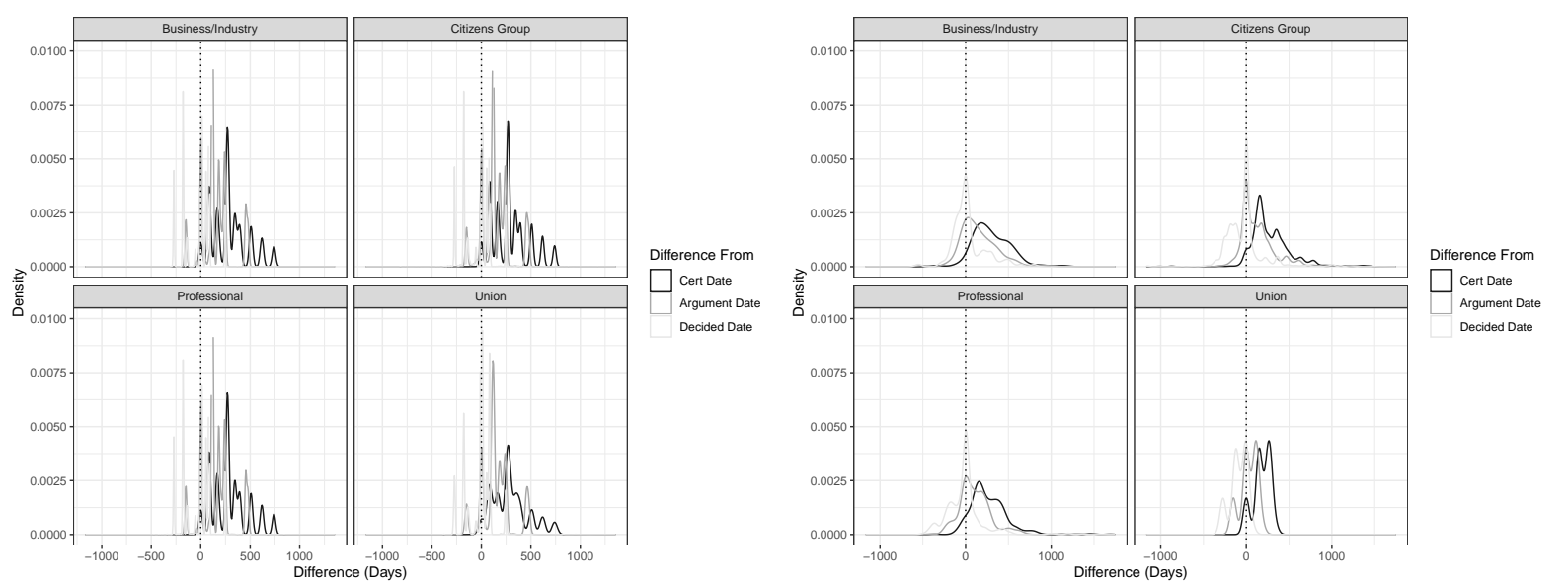

Figure 7: Difference in days from Facebook and Twitter posts about Supreme Court case to the cert, argument, or decision date, divided by group type.

\section{Discussion and Conclusion}

This paper examines interest groups' social media posts about courts and judicial advocacy. Overall, these posts constitute a small proportion of interest groups' overall social media activity; they make up less than $2 \%$ of the total Facebook posts and less than $1 \%$ of total tweets in our two datasets of federally-focused interest and filers of Supreme Court amicus briefs from 2016 to 2020. While the proportion of posts of this type is small, we have argued that interest groups use them strategically to advance two key goals: public education and organizational maintenance. Posting about the courts may help an interest group build the public's understanding of its issues, build a reputation as a trusted source of information, and obtain the membership and financial resources needed to continue to advance its policy goals.

We find support for our hypotheses that interest groups are in fact using social media in these ways. Interest group organizations use Facebook and Twitter to post about court-related topics. Citizens' groups, which are least likely to need to offer selective incentives and most likely to value public education, post most frequently about the courts. Organizations that engage in amicus activity post about that activity to credit claim about their efforts. Legal organizations, which have additional incentives to promote their expertise and litigation experience, post most frequently about courts generally and about their amicus activity. This supports the idea that interest groups 
have embraced social media as a wide-reaching, inexpensive avenue for credit claiming. This paper introduces a modern way that groups can credit claim at the Supreme Court and highlights the importance of technology in interest group activity about the courts.

Our analysis also raises interesting questions for future research. First, the relatively high rate of posts about amicus brief filings in state and lower federal courts we saw in our content analysis suggests that interest group involvement in amicus filings in these courts is more common than the literature's emphasis on the Supreme Court suggests. It is particularly notable that organizations that are federally-focused still take an active interest in state court cases - enough so to file briefs and post about developments. Our measure of amicus briefs here considers only Supreme Court cases, but future work ought to excavate these patterns more specifically at the lower court level, or at state supreme courts.

Second, the content of amicus posts seems to emphasize the value of coalitions and partnerships in legal advocacy. Highlighting other groups advocating around the same issue could be seen to diminish, rather than enhance, an organization's ability to fundraise or gain members through credit claiming. Why, then, do groups do this? Do groups that need co-filers more because their legal resources are more limited, do this more frequently to demonstrate that they are good partners? Or are strong groups that want to encourage collaboration more likely to do this because they know having the support of other organizations strengthens their position? Examining coalition behavior could be a fruitful area for future work.

Another interesting, but outstanding, question is whether groups try to claim credit on social media for litigation that they were not involved in at all. This leads to a broader question of whether the credit claiming actually works: that is, do the groups' members or the broader public pay attention to this activity or the posts about it? Are they able to credibly credit claim if the audience is not recognizing that activity? Exploring these issues is an essential extension of research on amicus briefs in an increasing prevalent social media context. Our initial analysis about posts from non-amicus filers does indeed that this is less common within these groups, but 
it is not nonexistent. This suggests even those groups that are not directly involved in outcomes of particular Supreme Court cases may be falsely claiming credit for their outcomes.

This project provides new information about how social media may be an essential avenue for organizations to educate the public and credit claim about their litigation activity. This is an important addition to the literature on how groups may use amicus briefs to credit claim and how they publicize that activity (Collins 2018, Hansford 2004ab), as well as to our overall understanding of the many motivations and strategies that shape interest groups' use of social media. Our paper suggests that modern technology and social media is a useful tool in the interest group toolbox, and one that can emphasize litigation efforts and court activities more broadly.

\section{References}

Ansley, Taylor and Patrick Sellers. 2010. Mobilizing to Frame Election Campaigns. In Winning with Words: The Origins \& Impact of Political Framing, ed. Brian Schaffner and Patrick Sellers. New York: Routledge pp. 78-98.

Baumgartner, Frank R and Beth L Leech. 1998. Basic Interests: The Importance of Groups in Politics and in Political Science. Princeton University Press.

Berry, Jeffrey M. 1977. Lobbying for the People: The Political Behavior of Public Interest Groups. Princeton University Press.

Berry, Jeffrey M. 2003. A Voice for Nonprofits. Brookings Institution Press.

Bils, Peter, Lawrence S. Rothenberg and Bradley C. Smith. 2020. "The Amicus Game.” The Journal of Politics 82(3).

Bortree, Denise Sevick and Trent Seltzer. 2009. "Dialogic strategies and outcomes: An analysis of environmental advocacy groups' Facebook profiles." Public relations review 35(3):317-319.

Box-Steffensmeier, Janet M., Dino P. Christenson and Matthew P. Hitt. 2013. "Quality Over 
Quantity: Amici Influence and Judicial Decision Making." American Political Science Review pp. $446-460$.

Brown, Heath. 2015. “The Institutional Digital Divide: Immigrant-Serving Nonprofit Organization Adoption of Social Media." Social Science Computer Review 33(6):680-695.

Browne, William P. 1998. Groups, Interests, and US Public Policy. Georgetown University Press.

Buckler, Kevin G. 2015. "Supreme Court Outcomes in Criminal Justice Cases (1994-2012 Terms) An Examination of Status Differential and Amici Curiae Effects." Criminal Justice Policy Review 26(8):773-804.

Caldeira, Gregory A. and John R. Wright. 1988. “Organized Interests and Agenda Setting in the US Supreme Court.” The American Political Science Review pp. 1109-1127.

Caldeira, Gregory A. and John R. Wright. 1998. "Lobbying for Justice: Organized Interests Supreme Court Nominations, and United States Senate.” American Journal of Political Science pp. 499-523.

Caldeira, Gregory A., Marie Hojnacki and John R. Wright. 2000. "The Lobbying Activities of Organized Interests in Federal Judicial Nominations.” Journal of Politics 62(1):51-69.

Chalmers, Adam William. 2013. "Trading information for access: informational lobbying strategies and interest group access to the European Union.” Journal of European Public Policy 20(1):39-58.

Chalmers, Adam William and Paul Alexander Shotton. 2016. "Changing the face of advocacy? Explaining interest organizations' use of social media strategies." Political Communication 33(3):374-391.

Chang, Robert S. and Karin Wang. 2008. "Democratizing the Courts: How an Amicus Brief Helped Organize the Asian American Community to Support Marriage Equality." Asian Pacific American Law Journal 14:22. 
Christenson, Dino P. and Janet M. Box-Steffensmeier. 2017. Why Amicus Curiae Cosigners Come and Go: A Dynamic Model of Interest Group Networks. In Complex Networks \& Their Applications V, ed. Hocine Cherifi, Sabrina Gaito, Walter Quattrociocchi and Alessandra Sala. Cham: Springer International Publishing pp. 349-360.

Collins, Paul M. Jr. 2004. "Friends of the Court: Examining the Influence of Amicus Curiae Participation in U.S. Supreme Court Litigation.” Law \& Society Review 38(4):807-832.

Collins, Paul M. Jr. 2008. Friends of the Supreme Court: Interest Groups and Judicial Decision Making. Oxford University Press.

Collins, Paul M. Jr. 2018. "The Use of Amicus Briefs." Annual Review of Law and Social Science $14: 219-237$.

Collins, Paul M. Jr. and Lisa A. Solowiej. 2007. "Interest Group Participation, Competition, and Conflict in the US Supreme Court.” Law \& Social Inquiry 32(4):955-984.

Collins, Paul M. Jr., Pamela C. Corley and Jesse Hamner. 2015. “The Influence of Amicus Curiae Briefs on U.S. Supreme Court Opinion Content.” Law \& Society Review 49(4):917-944.

Edwards, Linda H. 2017. "Telling Stores in the Supreme Court: Voices Briefs and the Role of Democracy in Constitutional Deliberation.” Yale Journal of Law \& Feminism 29:29.

Epp, Charles R. 1998. The Rights Revolution: Lawyers, Activists, and Supreme Courts in Comparative Perspective. University of Chicago Press.

Epstein, Lee. 1992. “Interest Group Litigation During the Rehnquist Court Era.” Journal of Law \& Politics 9:639.

Figenschou, Tine Ustad and Nanna Alida Fredheim. 2020. "Interest groups on social media: Four forms of networked advocacy." Journal of Public Affairs 20(2):1-8.

Gainous, Jason and Kevin Wagner. 2014. Tweeting to Power: The Social Media Revolution in American Politics. Oxford University Press. 
Garcia, Ruben J. 2007. “A Democratic Theory of Amicus Advocacy.” Florida State University Law Review 35:315.

Giles, Michael W. and Thomas G. Walker. 1975. “Judicial Policy-Making and Southern School Segregation.” The Journal of Politics 37(4):917-936.

Golbeck, Jennifer, Justin Grimes and Anthony Rogers. 2010. "Twitter use by the US Congress." Journal of the American Society for Information Science and Technology 61(8):1612-1621.

Graber, Mark A. 2006. "Legal, strategic or legal strategy: Deciding to decide during the civil war and reconstruction..".

Grossmann, Matt. 2012. The Not-So-Special Interests: Interest Groups, Public Representation, and American Governance. Stanford University Press.

Guo, Chao and Gregory D. Saxton. 2014. "Tweeting Social Change: How Social Media Are Changing Nonprofit Advocacy." Nonprofit and Voluntary Sector Quarterly 43(1):57-79.

Guo, Chao and Gregory D. Saxton. 2020. The Quest for Attention: Nonprofit Advocacy in a Social Media Age. Stanford University Press.

Guo, Chao and Juliet A Musso. 2007. "Representation in nonprofit and voluntary organizations: A conceptual framework." Nonprofit and Voluntary Sector Quarterly 36(2):308-326.

Hansford, Thomas G. 2004a. "Information Provision, Organizational Constraints, and the Decision to Submit an Amicus Curiae Brief in a U.S. Supreme Court Case.” Political Research Quarterly 57(2):219-230.

Hansford, Thomas G. 2004b. "Lobbying Strategies, Venue Selection, and Organized Interest Involvement at the US Supreme Court." American Politics Research 32(2):170-197.

Hazelton, Morgan LW, Rachael K Hinkle and James F Spriggs. 2019. "The Influence of Unique Information in Briefs on Supreme Court Opinion Content.” Justice System Journal 40(2):126157. 
Hemphill, Libby, Aron Culotta and Matthew Heston. 2013. "Framing in social media: How the US Congress uses Twitter hashtags to frame political issues.” Available at SSRN 2317335 .

Holyoke, Thomas T. 2003. “Choosing Battlegrounds: Interest Group Lobbying Across Multiple Venues.” Political Research Quarterly 56(3):325-336.

Ivers, Gregg and Karen O’Connor. 1987. "Friends as Foes: The Amicus Curiae Participation and Effectiveness of the American Civil Liberties Union and Americans for Effective Law Enforcement in Criminal Cases, 1969-1982.” Law \& Policy 9(2):161-178.

Johnson, Dennis. 2011. Campaigning in the twenty-first century: A whole new ballgame? Routledge.

Kearney, Joseph D. and Thomas W. Merrill. 2000. “The Influence of Amicus Curiae Briefs on the Supreme Court.” University of Pennsylvania Law Review 148(3):743-855.

Larsen, Allison Orr and Neal Devins. 2016. “The amicus machine.” Va. L. Rev. 102:1901.

Lovejoy, Kristen, Richard D Waters and Gregory D Saxton. 2012. "Engaging stakeholders through Twitter: How nonprofit organizations are getting more out of 140 characters or less." Public relations review 38(2):313-318.

Lynch, Kelly J. 2004. "Best Friends? Supreme Court Law Clerks on Effective Amicus Curiae Briefs.” Journal of Law \& Politics 20:33.

Macdonald, Maggie. 2020. “Money Please! Testing the Interest Group Connection.” Working Paper.

Mak, Maxwell, Andrew H. Sidman and Udi Sommer. 2013. "Is Certiorari Contingent on Litigant Behavior? Petitioners' Role in Strategic Auditing." Journal of Empirical Legal Studies $10(1): 54-75$.

Martinek, Wendy L. 2006. “Amici Curiae in the US Courts of Appeals.” American Politics Research 34(6):803-824. 
McCann, Michael. 2006. "Law and Social Movements: Contemporary Perspectives." Annual Review of Law and Social Science 2:17-38.

McGregor, Shannon C and Logan Molyneux. 2020. "Twitter's influence on news judgment: An experiment among journalists." Journalism 21(5):597-613.

McGuire, Kevin T. 1995. "Repeat Players in the Supreme Court: The Role of Experienced Lawyers in Litigation Success.” The Journal of Politics 57(1):187-196.

Nownes, Anthony J and Patricia Freeman. 1998. "Interest Group Activity in the States." The Journal of Politics 60(1):86-112.

Obar, Jonathan A, Paul Zube and Clifford Lampe. 2012. "Advocacy 2.0: An analysis of how advocacy groups in the United States perceive and use social media as tools for facilitating civic engagement and collective action.” Journal of information policy 2:1-25.

O’Connor, Karen and Lee Epstein. 1982. “The Importance of Interest Group Involvement in Employment Discrimination Litigation." Howard Law Journal 25:709.

Olson, Mancur. 1965. The Logic of Collective Action. Vol. 124 Harvard University Press.

Olson, Susan M. 1990. “Interest-Group Litigation in Federal District Court: Beyond the Political Disadvantage Theory." The Journal of Politics 52(3):854-882.

Owens, Ryan J. and Lee Epstein. 2005. "Amici Curiae During the Rehnquist Years.” Judicature $89: 127$.

Pope, James Gray. 1990. "Republican moments: the role of direct popular power in the American constitutional order." U. Pa. L. Rev. 139:287.

Salzman, Ryan, Christopher J. Williams and Bryan T. Calvin. 2011. "The Determinants of the Number of Amicus Briefs Filed Before the U.S. Supreme Court, 1953-2001.” Justice System Journal 32(3):293-313. 
Scheingold, Stuart A. 1974. The Politics of Rights: Lawyers, Public Policy, and Political Change. Yale University Press.

Schlozman, Kay Lehman and John T. Tierney. 1986. Organized Interests and American Democracy. Harper and Row.

Segal, Jeffrey A., Charles M. Cameron and Albert D. Cover. 1992. "A Spatial Model of Roll Call Voting: Senators, Constituents, Presidents, and Interest Groups in Supreme Court Confirmations." American Journal of Political Science pp. 96-121.

Shapiro, Martin. 1989. "Interest Groups and Supreme Court Appointments.” Northwestern University Law Review 84:935.

Simmons, Omari Scott. 2009. "Picking Friends from the Crowd: Amicus Participation as Political Symbolism.” Connecticut Law Review 42:185.

Solberg, Rorie Spill and Eric N. Waltenburg. 2006. "Why Do Interest Groups Engage the Judiciary? Policy Wishes and Structural Needs.” Social Science Quarterly 87(3):558-572.

Songer, Donald R. and Ashlyn Kuersten. 1995. "The Success of Amici in State Supreme Courts." Political Research Quarterly 48(1):31-42.

Songer, Donald R. and Reginald S. Sheehan. 1993. "Interest Group Success in the Courts: Amicus Participation in the Supreme Court." Political Research Quarterly 46(2):339-354.

Spriggs, James F. and Paul J. Wahlbeck. 1997. "Amicus Curiae and the Role of Information at the Supreme Court.” Political Research Quarterly 50(2):365-386.

Van der Graaf, Amber, Simon Otjes and Anne Rasmussen. 2016. "Weapon of the Weak? The Social Media Landscape of Interest Groups.” European Journal of Communication 31(2):120135.

Vining, Richard L. Jr. 2011. "Grassroots Mobilization in the Digital Age : Interest Group Response to Supreme Court Nominees." Political Research Quarterly 64(4):790-802. 
Walker, Jack L. 1991. Mobilizing Interest Groups in America: Patrons, Professions, and Social Movements. University of Michigan Press.

Widner, Kirsten, Maggie Macdonald and Anna Gunderson. 2020. "Lobbying Inside (and) Out: Interest Group Behavior on Social Media.” Working Paper.

Wofford, Claire B. 2015. "Assessing the Anecdotes: Amicus Curiae, Legal Rules, and the U.S. Supreme Court.” Justice System Journal 36(3):274-294.

Wofford, Claire B. 2020. "Why Try? Comparing the Aims of Parties and Amici in US Supreme Court Litigation.” Justice System Journal pp. 1-17.

Zuber, Katie, Udi Sommer and Jonathan Parent. 2015. "Setting the Agenda of the United States Supreme Court? Organized Interests and the Decision to File an Amicus Curiae Brief at Cert." Justice System Journal 36(2):119-137. 


\section{Appendix}

\section{Contents}

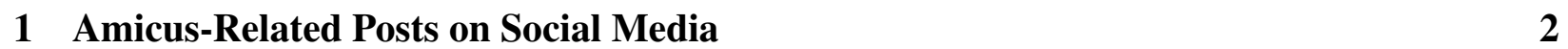

2 Comparing Likes and Shares of Court- and Amicus-Related Posts 3

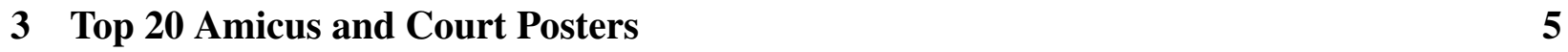

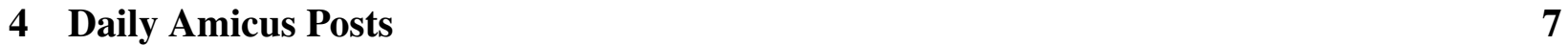




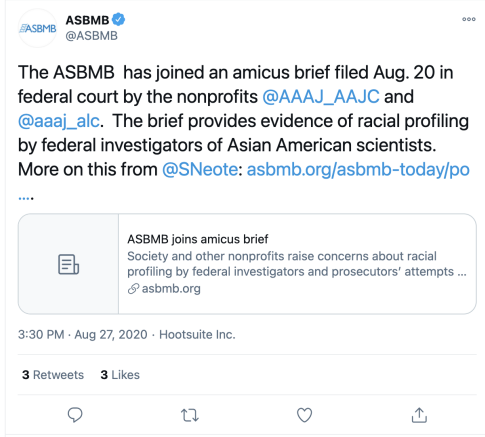

(a) Twitter Example 1

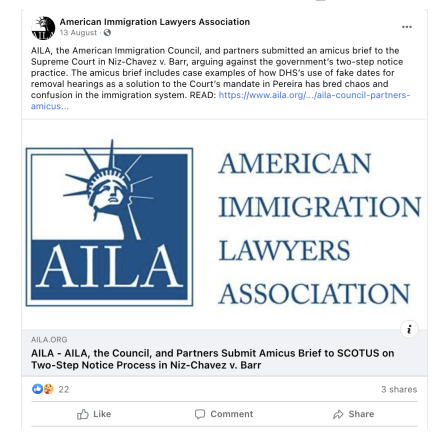

(c) Facebook Example 1

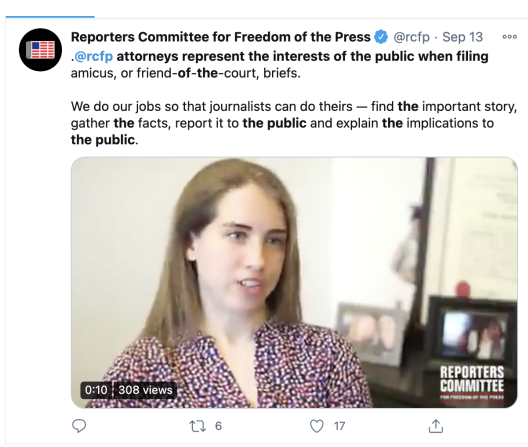

(b) Twitter Example 2

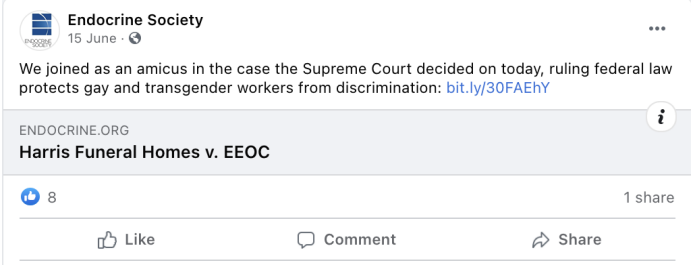

(d) Facebook Example 2

Figure 1: Examples of amicus-related posts on Facebook and Twitter.

\section{Amicus-Related Posts on Social Media}

We consider the more narrow subset of data as described above, only data that contains words like "friend of the court," "amici," or "amicus" to capture those posts about direct organization amicus activity. Figure 1 contains examples of posts coded in this category on Twitter (Figure 1 a and $1 \mathrm{~b}$ ) and Facebook (Figure $1 \mathrm{c}$ and $1 \mathrm{~d}$ ). These posts largely refer to these groups filing or joining other organizations on amicus briefs, though there are also examples of informing members about precisely why the organization files amicus briefs (Figure $1 \mathrm{~b}$ ).

Organizations are most often talking about either their own amicus briefs or about groups who are joining or sharing their position. All of these are topics that can fall under the umbrella of credit claiming; they claim credit for the organization's work and the influence it is having.

Does this posting activity differ by group type? The weekly average amicus posts for the four groups is shown in Figure 2. Though groups post less frequently about amicus briefs than they do about the courts generally, it is still notable that many of them choose to do so. Many of the same group-level patterns that we noted when considering posting about the courts can be seen here as well, with one important difference. Business and professional groups appear to be much more active in posting about their amicus work than they are in posting about the courts more generally. 


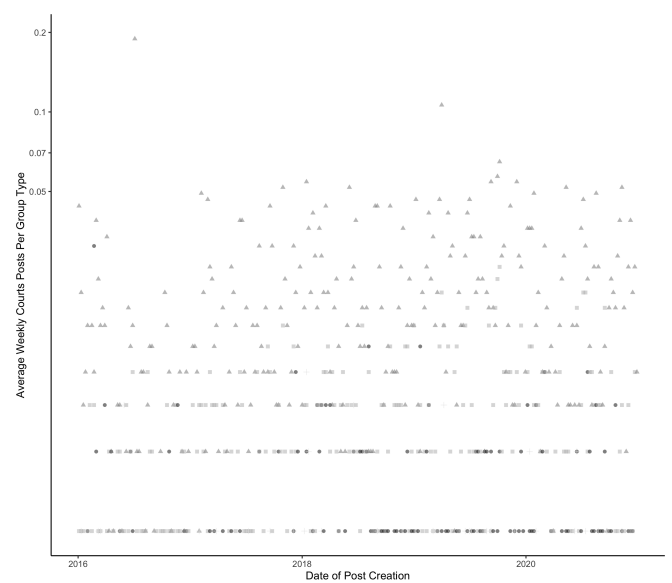

(a) Twitter

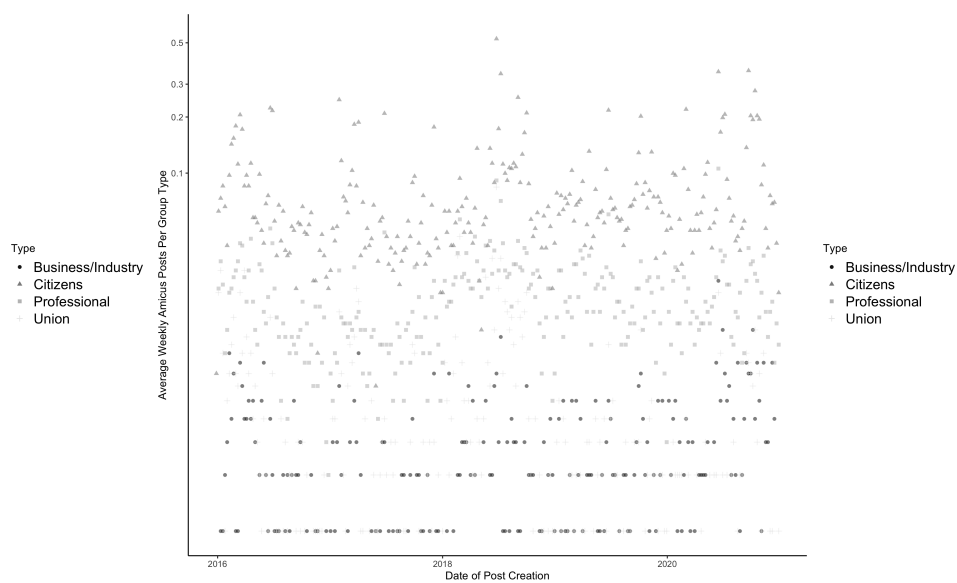

(b) Facebook

Figure 2: Weekly average amicus posts by group type, on Twitter $2 \mathrm{a}$ and Facebook $2 \mathrm{~b})$ from January 1, 2016 to December 31, 2020.

\section{Comparing Likes and Shares of Court- and Amicus-Related Posts}

One of the open questions from this analysis is the degree to which these posts are successful: that is, are they reaching and impacting their intended audiences? One way to evaluate success is to see whether the posts garner interactions from the public. As an initial examination, we compare the number of post favorites (on Twitter) and likes (on Facebook) across the two different subsets we analyze, courts-related and amicus-related posts. First, we see if there is a visual difference (see Figure 3 in the number of weekly likes for posts in our court and amicus categories separately. ${ }^{1}$

There appear to be significantly more likes on tweets and Facebook posts about general court activity than amicus briefs, but is this difference significant? Tables 1 and 2 contain a series of t-tests comparing the mean number of likes and shares by post type on Twitter and Facebook, respectively. The difference is highly significant and substantively large: posts and tweets about court-related activity net many more likes and shares than posts and tweets about amicus activity. In other words, readers are responding more positively to the information sharing posts than they are to the credit claiming posts. While this is a exploratory analysis, it does raise the question of why groups are spending time making credit claiming posts at all, if it is not garnering significant public attention or approval on these social media sites.

\footnotetext{
${ }^{1}$ The graphs for the number of post shares looks essentially identical.
} 


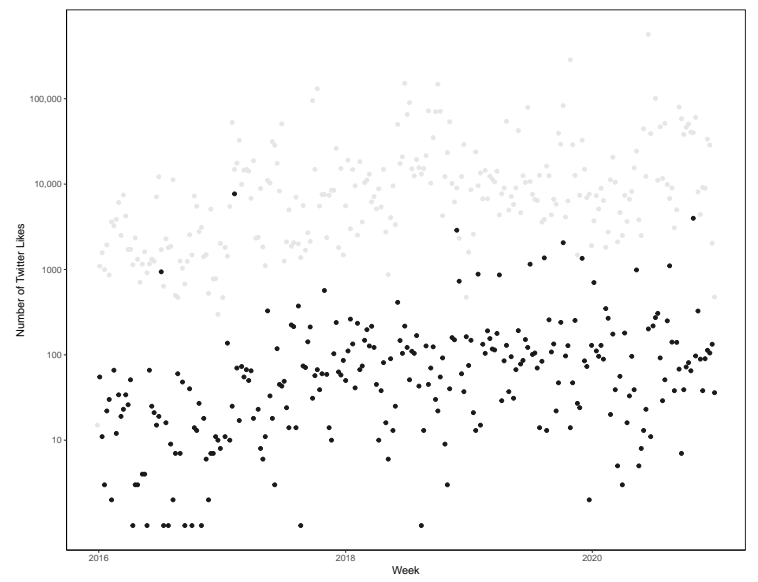

(a) Twitter

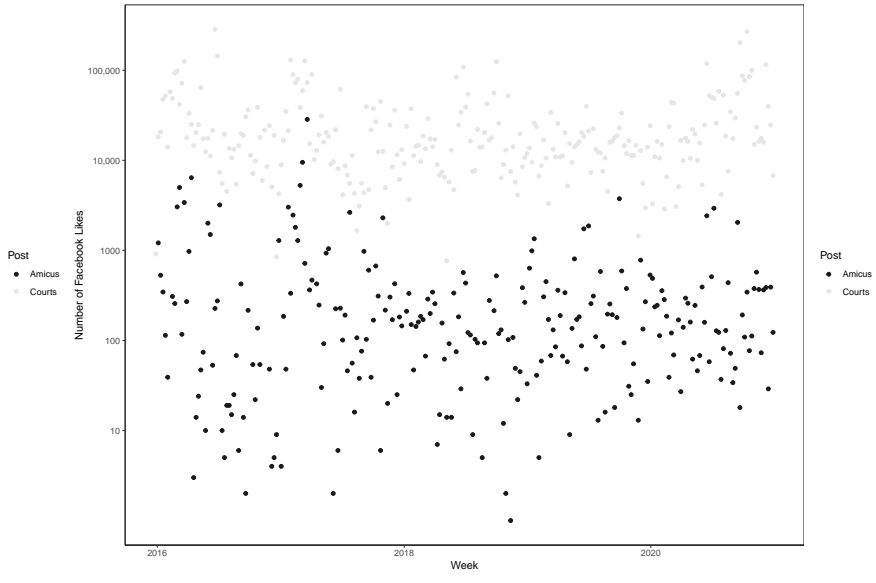

(b) Facebook

Figure 3: Weekly sum of posts on amicus- or court-related activity, on Twitter 3a and Facebook (3b) from January 1, 2016 to December 31, 2020.

\begin{tabular}{llrlr}
\hline & Variable & t.statistic & Confidence.Interval & p.value \\
\hline 1 & Likes & -6.75 & $-59.34,-32.63$ & 0.00 \\
2 & Retweets & -16.32 & $-116.42,-91.45$ & 0.00 \\
\hline
\end{tabular}

Table 1: Results from a Welch Two Sample t-test. Twitter posts about courts have 62 likes on average and 129.21 shares on average, compared to Twitter posts about amicus briefs that have 16.01 likes on average and 25.28 shares on average.

\begin{tabular}{llrlr}
\hline & Variable & t.statistic & Confidence.Interval & p.value \\
\hline 1 & Likes & -7.56 & $-240.55,-141.42$ & 0.00 \\
2 & Shares & -2.23 & $-119.46,-7.67$ & 0.03 \\
\hline
\end{tabular}

Table 2: Results from a Welch Two Sample t-test. Facebook posts about courts have 297.98 likes on average and 119.86 shares on average, compared to Facebook posts about amicus briefs that have 106.99 likes on average and 56.3 shares on average. 


\section{Top 20 Amicus and Court Posters}

Which organizations are the most frequent posters on Twitter and Facebook about amicus briefs? We first consider the top posters on Twitter. As it was with courts above, the majority of the top tweeters about amici are citizens' groups (9 out of the top 10). The NAACP Legal Defense and Education Fund posts the most, with 184 tweets. The next highest are the Juvenile Law Center (138 tweets), Human Rights Campaign (116 tweets), the Lawyers' Committee for Civil Rights Under Law (102 tweets), and Reporters Committee for Freedom of the Press (a professional group; 102 tweets). Rounding out the top ten are the Electronic Privacy Information Center, Center for Democracy and Technology, Americans United for Separation of Church and State, the AntiDefamation League, and the National Association of Criminal Defense Lawyers.

The most prolific groups on this topic on Facebook are all citizens' groups - the Lawyers' Committee for Civil Rights Under the Law (51 posts), CAIR (Council on American-Islamic Relations, 49 posts) the Juvenile Law Center (47 posts), the Electronic Privacy Information Center (34 posts), and the NAACP Legal Defense Fund (26 posts). Completing the top 10 most active posters on amici are more citizens' groups: Citizens United, the Center for Democracy and Technology, the Japanese American Citizens League, the Arc of the United States, and LatinoJustice PRLDEF. All of these groups posted over twenty times between January 2016 and the end of 2020. In contrast to the other group types, unions were not frequent posters on Twitter or Facebook. This suggests interesting and important differences across group type but also within types that we will explore more in the future.

There are a handful of power posters who were the most frequent posters across Twitter and Facebook - the NAACP Legal Defense Fund, the Juvenile Law Center, and the Electronic Privacy Information Center - though there are still notable differences between the most active posters on each platform. There seems to be strong similarities in overall trends between groups posting about amici on Twitter and Facebook, though there is interesting variation within groups. 


\begin{tabular}{|c|c|c|c|c|c|}
\hline & Facebook Page Name & Type & Posts & Twitter Page Name & Type \\
\hline 1 & Lawyers' Committee for Civil Rights Under Law & Citizens & 51 & NAACP Legal Defense and Education Fund & Citizens \\
\hline 2 & CAIR & Citizens & 49 & Juvenile Law Center & Citizens \\
\hline 3 & Juvenile Law Center & Citizens & 47 & Human Rights Campaign & Citizens \\
\hline 4 & EPIC - Electronic Privacy Information Center & Citizens & 34 & Lawyers' Committee for Civil Rights Under Law & Citizens \\
\hline 5 & NAACP Legal Defense Fund & Citizens & 26 & Reporters Committee for Freedom of the Press & Professional \\
\hline 6 & Citizens United & Citizens & 25 & Electronic Privacy Information Center & Citizens \\
\hline 7 & Center for Democracy \& Technology & Citizens & 24 & Center for Democracy and Technology & Citizens \\
\hline 8 & Japanese American Citizens League (JACL) & Citizens & 24 & Americans United for Separation of Church and State & Citizens \\
\hline 9 & The Arc of the United States & Citizens & 24 & Anti-Defamation League & Citizens \\
\hline 10 & LatinoJustice PRLDEF & Citizens & 23 & National Association of Criminal Defense Lawyers & Professional \\
\hline 11 & The Reporters Committee for Freedom of the Press & Professional & 23 & Washington Legal Foundation & Citizens \\
\hline 12 & American Association of University Professors & Professional & 21 & Credit Union National Association & Business/Indu \\
\hline 13 & Human Rights Campaign & Citizens & 20 & The Arc & Citizens \\
\hline 14 & Americans United for Separation of Church and State & Citizens & 19 & American Bar Association & Professional \\
\hline 15 & Native American Rights Fund & Citizens & 19 & Lawyers for Civil Justice & Business/Indu \\
\hline 16 & American Intellectual Property Law Association (AIPLA) & Professional & 18 & National Right to Work Committee & Citizens \\
\hline 17 & The Bazelon Center for Mental Health Law & Citizens & 18 & American Association of University Professors & Professional \\
\hline 18 & ADL - Anti-Defamation League & Citizens & 17 & National Senior Citizens Law Center & Citizens \\
\hline 19 & American Tort Reform Association & Citizens & 17 & Asian American Legal Defense and Education Fund & Citizens \\
\hline 20 & Taxpayers Against Fraud Education Fund & Citizens & 17 & Citizens United & Citizens \\
\hline
\end{tabular}

Table 3: The top 20 organizations who posted about amicus briefs on Facebook (left) and Twitter (right), as well as their type and the number of posts.

\begin{tabular}{rlrlll}
\hline & Facebook Page Name & Type & Posts & Twitter Page Name & Type \\
\hline 1 & The Federalist Society & Professional & 718 & People for the American Way \\
2 & CAIR & Citizens & 679 & NAACP Legal Defense and Education Fund \\
3 & ACLU & Citizens & 591 & American Constitution Society for Law and Public Policy & Critizens \\
4 & People For the American Way & Citizens & 578 & Alliance for Justice & Citizens \\
5 & American Constitution Society & Professional & 551 & Leadership Conference on Civil Rights \\
6 & Lawyers' Committee for Civil Rights Under Law & Citizens & 534 & NARAL Pro-Choice America & Citizens \\
7 & Death Penalty Information Center & Citizens & 436 & Americans United for Separation of Church and State & Citizens \\
8 & Center for Reproductive Rights & Citizens & 421 & Service Employees International Union \\
9 & Americans United for Separation of Church and State & Citizens & 407 & Lawyers' Committee for Civil Rights Under Law \\
10 & Alliance for Justice & Citizens & 401 & Family Research Council & Cnion \\
11 & NAACP Legal Defense Fund & Citizens & 349 & American Civil Liberties Union \\
12 & Family Research Council & Citizens & 306 & Federalist Society for Law and Public Policy Studies \\
13 & NARAL Pro-Choice America & Citizens & 289 & Center for Reproductive Rights \\
14 & National Council of Jewish Women (NCJW) & Citizens & 289 & American Bar Association & Crofessional \\
15 & Society for Human Resource Management (SHRM) & Professional & 280 & Sierra Club & Citizens \\
16 & Independent Women's Forum & Citizens & 271 & Human Rights Campaign & Citizens \\
17 & Mexican American Legal Defense and Educational Fund & Citizens & 268 & American Bankruptcy Institute \\
18 & Human Rights Campaign & Citizens & 257 & FreedomWorks & Citizens \\
19 & SEIU & Union & 252 & National Council of Jewish Women \\
20 & American Bar Association & Professional & 238 & Independent Women's Forum \\
\hline
\end{tabular}

Table 4: The top 20 organizations who posted about the courts on Facebook (left) and Twitter (right), as well as their type and the number of posts. 


\section{Daily Amicus Posts}
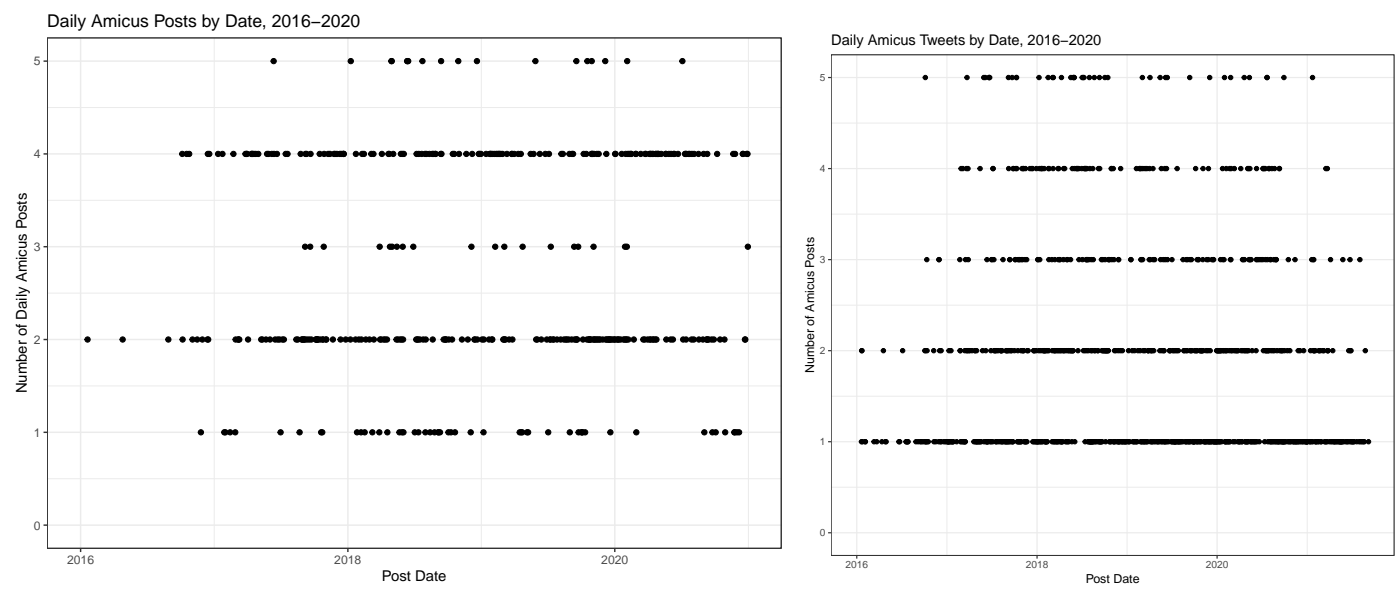

Figure 4: Daily amicus posts by organizations, 2016 to 2020 on Facebook (left) and Twitter (right). 